\title{
Complaints Musculoskeletal Disorders (MSDS) at Ulos Weaving Workers in Kelurahan X
}

\author{
Madschen Sia Mei Ol Siska Selvija Tambun \\ \{madshensia@unism.ac.id\} \\ Industrial Engineering Department, Sari Mulia University, J1. Scout 2, PemurusAffairs. \\ District. East Banjarmasin, Banjarmasin, South Kalimantan, 70 238, Indonesia
}

\begin{abstract}
The pupose of this study was to analyze the complaints symptons of MsDS at the weaver ulos who carried out the work ergonomics in Kelurahan X. This was an observational study. The population amounting to 20 people. The level of MSDs complaints that was felt by workers per part of the body using Nordic Body Map questionnaire. Distribution of MSDs based on age mostly occur on workers aged under 35 years, based on sex mostly occur on female workers, based on working experience mostly occur on workers which has been worked for 5 years or more and based on sport habit mostly occur on workers whish have no habit of working out sports. Nordic Body Map Questionnaire results about MSDs complaints were many who complained on the back waist (70\%), right shoulder (55\%), upper neck (45\%).
\end{abstract}

Keywords: Ergonomics, MSDs complaints, Ulos Weaving Workers

\section{Introduction}

Every worker needs safe and comfortable working conditions. These conditions must be supported by a work environment that is conducive for workers to do their work so that the work can be done effectively and efficiently. Unsafe and comfortable work environment conditions can make a job obstructed and also can reduce the health status of workers. Besides being able to reduce the degree of health of workers can also cause fatigue and can lead to accidents.

Musculoskeletal Disorders (MsDS) is one of the common health problems throughout the world caused by a mismatch or discomfort at work. This is supported by research journals in 16 production units or as many as 454 rubber factory workers in Iran who are chosen randomly. The results showed that the majority of workers $(73.6 \%)$ suffered from several symptoms of Musculoskeletal Disorders (MsDS) during the last 12 months. The highest prevalence of worker complaints was found in the lower back (50.2\%), knee (48.5\%), and upper back (38.1\%) [1].

The correct application of ergonomics in the workplace aims to ensure that workers at work are always healthy, comfortable, safe, productive and prosperous. Conversely, if the application of ergonomics is done incorrectly, it will result in complaints, occupational diseases from workers due to their work. The Labor Force Survey (LFS) in the UK reports that in 2017/2018 an estimated 469,000 workers in the UK suffered from Musculoskeletal disorders. This data is equivalent to 6.6 million lost work days in the UK. 
Of these, 186,000 (40\%) were estimated to suffer from back trauma, 197,000 (42\%) had upper body or neck disorders, and 86,000 (18\%) had lower body health [2]. Whereas for Indonesia based on the results of health research, the prevalence of musculoskeletal diseases in Indonesia based on those diagnosed by health workers is $11.9 \%$ and based on diagnosis or symptoms that is $24.7 \%$. The prevalence based on the diagnosis of health workers was highest in Bali $(19.3 \%)$, followed by Aceh (18.3\%), West Java (17.5\%) and Papua (15.4\%). The highest prevalence in the work of farmers, fishermen, laborers both diagnosed by health workers $(15.3 \%)$ and diagnoses of health workers or symptoms $(31.2 \%)$ [3].

The cause of musculoskeletal complaints is excessive muscle stretching, repetitive activity and unnatural work attitude. The risk factors for musculoskeletal complaints include individual factors (age, sex, length of service, exercise habits) and work factors (weight, duration, work posture, and repetition / frequency) and environmental factors (vibration and temperature exposure) [4].

Based on an initial survey conducted by researchers that there are musculoskeletal complaints that are often experienced by workers weaving ulos on body parts. One of the factors that influence musculoskeletal complaints is age, sex, length of service and exercise habits. Therefore, the authors are interested in conducting a musculoskeletal complaint analysis research if reviewed based on individual factors (age, sex, length of service and exercise habits) on ulos weaving workers in Kelurahan X.

\section{Materials And Methods}

This research is a descriptive analytic study using a cross sectional approach. The population in this study were all ulos weavers in Kelurahan X, amounting to 20 people. The research instrument used was a questionnaire sheet containing information related to work information, health information and the Nordic Body Map. The implementation of this research is March 2012.

\section{Results And Discussion}

\subsection{Individual Characteristic}

The distribution of individual factors (age, sex, length of work and exercise habits) to ulos weaving workers can be seen in the information below:

a. Age

Ulos weaving workers have age variable distribution as follows :

Table 1. Age Distribution of Workers

\begin{tabular}{|c|c|c|}
\hline Age Variabel & Frequency & $(\%)$ \\
\hline$<35$ & 16 & 80 \\
\hline$\geq 35$ & 4 & 20 \\
\hline
\end{tabular}

From table 1 above shows that the age distribution of respondents at most is <35 years old with as many as 16 people $(80 \%)$. As for the age group $\geq 35$ years it is a small age 
group, amounting to 4 people (20\%). This is because the productive age affects the workprocess.

The older a person is, the higher the risk of muscle complaints. From the table above there are 4 workers who ulos weaving which will be very high risk of experiencing muscle complaints in line with the decrease in muscle strength due to increasing age and getting older.

The older a person is, the higher the risk of age related to events related to musculoskeletal disorders is that in old age causes physical and cell structure changes in the human body. At the age of 20 or 25 years maturity will occur and will stop its growth and begin to appear at the age of approximately 30 years, then there will be a process of decreasing the number and size of functional units in each body system marked by a decrease in the body's ability to adapt or recover from an stimulation [5]. A similar opinion was expressed by the study that there was a significant relationship between age and musculoskeletal complaints wherein the study of written batik workers in Surakarta aged over 30 years had a higher risk of musculoskeletal disorders than workers who were under 30 years of age [6]. Likewise, it was also stated that the maximum muscle strength only occurs at the age of 20-29 years and will decrease up to $20 \%$ at the age of 60 years [4]. The occurrence of muscle complaints. From the table above there are 4 workers who ulos weaving which will be very high risk of experiencing muscle complaints in line with the decrease in muscle strength due to increasing age and getting older.

b. Gender

Ulos weaving workers have the following gender variable distribution:

Table 2. Distribution of Workers Gender

\begin{tabular}{|c|c|c|}
\hline Gender & Frequency & $(\%)$ \\
\hline Man & 0 & 0 \\
\hline Woman & 20 & 100 \\
\hline
\end{tabular}

From table 2 above shows that the distribution of gender variable respondents is dominated by women as many as 20 people $(100 \%)$. Whereas there is no male gender $(0 \%)$. If you look at the data above, it is more appropriate for women to do ulos weaving work. This is because the ulos weaving job requires a high level of perseverance because one of the weaving processes of ulos itself enters or connects the yarn to the weaving comb to form the desired floral motif. Whereas for men usually rely more on physical strength, besides that in carrying out daily activities women tend to be less physically active with high metabolic habits.

Women do more sitting, silence, writing activities than doing activities that exert excess energy. This is also consistent with research on Aleyya Written Batik workers in Yogyakarta where batik workers are dominated by women [7]. If we see in terms of the characteristics of work between batik and ulos, it can be said that both of their jobs are more in demand by women. In addition to the position of work is to sit for a long time so it is more suitable for female workers than men.

The relationship between sex and musculoskeletal disorders is related to the opinion of experts in the medical field which conveys that the quantitative value of female muscle 
strength varies between two-thirds to three-fourths compared to men [8]. Tarwaka also mentioned that gender was associated with muscle risk [4].

\section{c. Working Period}

Ulos weaving workers have the following variable working period:

Table 3. Distribution of Working Period of Workers

\begin{tabular}{|c|c|c|}
\hline Working Period (year) & Frequency & $(\%)$ \\
\hline$<5$ & 7 & 35 \\
\hline$\geq 5$ & 13 & 65 \\
\hline
\end{tabular}

From table 3 above shows that the distribution of respondents based on years of work $<5$ years is as many as 7 people (35\%). Whereas for the group of workers with a work period of $\geq 5$ years as many as 13 people $(65 \%)$.

Working period is an accumulation of one's work activities carried out in the long term. If the activity is carried out continuously for a long period of time can cause interference with the body. The work period causes a constant static burden and workers who do not pay attention to ergonomic factors can cause musculoskeletal complaints [9].

Musculoskeletal complaints will increase as the work period of workers increases, which allows physical and psychological saturation. Work period is one of the risk factors that can affect aworker experiencing musculoskeletal disorders, especially for jobs that use high strength [4].

The statement put forward by Tarwaka, is in line with the results of research conducted on stone transport women workers that there is a relationship between age and musculoskeletal complaints [10].

\section{d. Sport Habit}

Ulos weaving workers have a variable distribution of exercise habits as follows :

Table 4. Distribution of Physical Freshness \& Physical Strength

\begin{tabular}{|c|c|c|}
\hline Sport Habit & Frequency & $(\%)$ \\
\hline Yes & 4 & 20 \\
\hline No & 16 & 80 \\
\hline
\end{tabular}

From table 4 above shows the distribution of the variable exercise habits in which workers who exercise as many as 4 people (20\%) more than workers who do not exercise as many as 16 people $(80 \%)$.

According to ulos weaving workers which are dominated by women workers consider that exercising is a waste of time. Because their time has been consumed by work and household activities. Both the activities of weaving ulos and doing household chores have drained them physically. In addition, they must pursue a daily target to weave ulos (in one day approximately 6 ulos must be produced). Due to various factors, the ulos weaving worker felt no need to exercise. And if they have free time, they will be more used to resting. 


\subsection{Musculoskeletal Disorder of Weaving Ulos Worker}

Musculoskeletal complaints measurement of musculoskeletal complaints in ulos weaving workers was carried out using the Nordic Body Map Questionnaire. Overall musculoskeletal complaints from 20 ulos weaving workers can be seen in the graphic below:

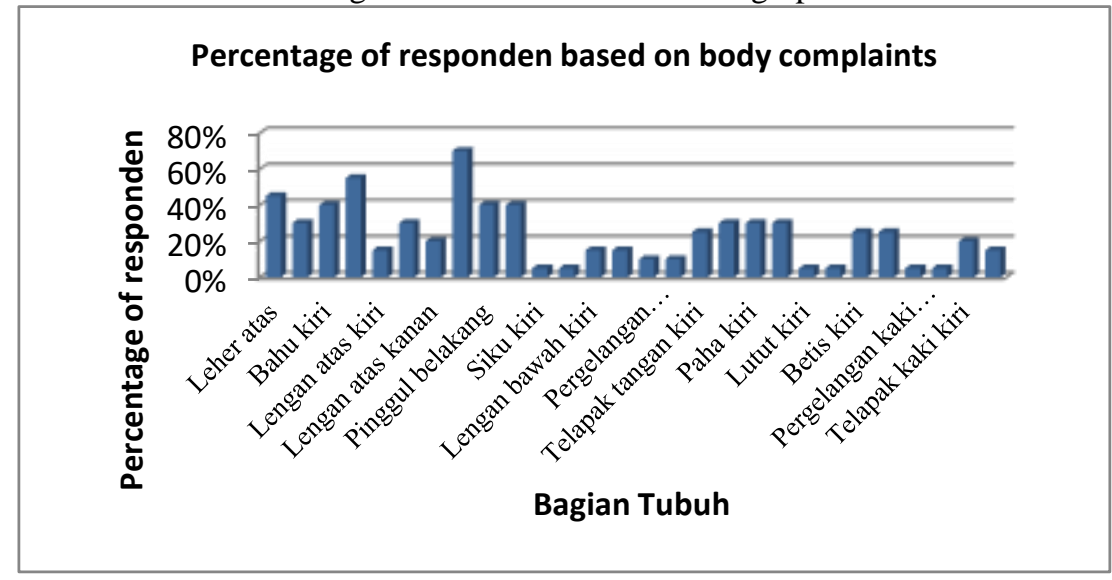

Fig. 1. Graphic of MsDS Complaints Per Body Part

If you see the picture above shows that the musculoskeletal complaints in the body part is dominated by the body part, the back waist $(70 \%)$. Then followed by the right shoulder $(55 \%)$ and upper neck (45\%), for more than one part of the body there were complaints on the left shoulder, back hips and buttocks, each at $40 \%$. While the least amount is found in the body parts of the left elbow, right elbow, left knee, right knee, left ankle, right ankle at 5\%.

Complaints that have known the results through the use of the Nordic Body Map Questionnaire for each individual ulos weaving worker can also be used to determine the level of musculoskeletal complaints based on the total individual score. The following are the results of calculating the level of musculoskeletal complaints, can be seen in table 5 below:

Table 5. Distribution of Complaints Rates of Worker MSDs

\begin{tabular}{|l|c|c|}
\hline \multicolumn{1}{|c|}{ MsDS } & $\Sigma$ & $\%$ \\
\hline High Risk & 7 & 35 \\
\hline Middle Risk & 13 & 65 \\
\hline Low Risk TOTAL & 0 & 0 \\
\hline \multicolumn{1}{|c|}{ TOT } & 20 & 100 \\
\hline
\end{tabular}

From table 5 above shows that of the 20 ulos weaving workers who felt the level of severe musculoskeletal complaints were 7 people $(35 \%)$ and who felt the level of moderate musculoskeletal complaints were 13 people $(65 \%)$. And there are no workers who feel the level of 
mild MsDS complaints. For workers who experience severe and moderate levels of musculoskeletal complaints, remedial action is needed in the future.

The level of musculoskeletal complaints tends to lead to moderate and severe complaints, based on observations it can be caused by ulos looms not designed by considering ergonomic aspects such as worker chairs that do not have a backrest that is useful for supporting the back of the body. High rates of musculoskeletal complaints are also experienced by Silungkang traditional songket craftsmen in West Sumatra. Traditional songket artisans also experience high levels of musculoskeletal complaints due to non-ergonomic work tools, large work areas that require workers to reach or other odd postures [11].

In workers who are predominantly performing seated activities, the parts of the body that usually experience interference are the waist, back and neck. In the sitting position, the spine (vertebral), especially at the waist (scarum, lumbar and thoracic) must be supported properly by the back of the chair to avoid pain (back pain) and fatigue (fatigue).

\section{References}

[1] Choobineh, Alireza, et al. 'Musculoskeletal Problems among Workers of an Iranian Rubber Factory'. Jurnal of Occupational Helath. Vol. 49. pp.418-423. (2007).

[2] Health and Safety Executive Annual Statistics. 'Work Related Musculoskeletal Disorders in Great Britain (WRMSDs). http://www.hse.gov.uk/statistics/causdis/msd.pdf [17 Juni 2019]. (2018).

[3] Balitbang Kemenkes RI. Riset Kesehatan Dasar. RISKESDAS: Jakarta. (2013).

[4] Tarwaka. Ergonomi Industri. Dasar-Dasar Pengetahuan Ergonomi dan Aplikasi di Tempat Kerja. Penerbit Harapan Press: Solo. (2010).

[5] Tilarso, H. Latihan Fisik dan Usia Tua, Majalah Cermin Dunia Kedokteran No.48. p. 19-21, http://www.scribd.com/doc/7538178/Cdk-048-Usia Lanjut [17 Juni 2019]. (1988).

[6] Sumardiyono, et al. Faktor Risiko Kesehatan Kerja Pada Pekerja Pembatik Tulis. Prosiding SNST Ke9. Fakultas Teknik Universitas Wahid Hasyim. (2018).

[7] Lindawati dan Mulyono, Evaluasi Postur Kerja Pengrajin Batik Tulis Aleyya Batik di Yogyakarta. JPH Recode. Vol. 1. No.2. (2018).

[8] Guyton, M.D. Buku Ajar Fisiologi Kedokteran. Jakarta: EGC. p. 374. (1994).

[9] Ayuningtyas, Santie. Hubungan antara Masa Kerja dan Resiko Terjadinya Nyeri Punggung Bawah pada Karyawan PT. Krakatau Steel. Universitas Muhammadiyah Surakarta. (2012).

[10] Arlina, Zakiah, et al. Analisis Risiko Ergonomi dan Keluhan Musculoskeletal Disorders (MsDS) Pada Pekerja Wanita Pengangkut Batu Bata di Desa Pangkalan Benteng Kecamatan Talang Kelapa Kabupaten Banyuasin. Jurnal Kedokteran dan Kesehatan. Vol. 4. p.149-158. (2017).

[11] Elza, Delti Selvina. Gambaran Tingkat Resiko Ergonomi dan Keluhan Subjektif Musculoskeletal Disorders Pada Pengrajin Songket Tradisional Silungkang di Sumatera Barat. Universitas Indonesia. (2012). 